\title{
The perceptions of Unified Health System (Sistema Único de Saúde) users about including undergraduate students in Family Health Units (Unidades de Saúde da Família)
}

\author{
Patricia Driusso" ${ }^{1}$, Tatiana 0. Sato ${ }^{1}$, Regina H. V. T. Joaquim ${ }^{2}$,
} Ana S. Moccellin ${ }^{3}$, Silvia H. Z. Mascarenhas ${ }^{4}$, Tania F. Salvini ${ }^{1}$

\begin{abstract}
Background: Curriculum guidelines for health professionals in training recommend including health students in different levels of service in the Unified Health System (Sistema Único de Saúde - SUS). Thus, there is a need to investigate the perceptions of SUS users with regard to the students' participation. Objective: To evaluate the perceptions of SUS users about the participation of health students in Family Health Units (Unidades de Saúde da Família - USF). Method: A total of 518 people were interviewed in the waiting room of eight USFs in São Carlos/São Paulo. The interviews were conducted by students using a semi-structured questionnaire, and the data were analyzed descriptively.

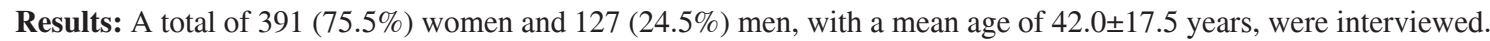
Among these users, $33.1 \%$ had encountered students in the USF, mainly while receiving clinical care (52.1\%) or during home visits $(20.1 \%)$; $55.3 \%$ considered the student's performance very good, and $0.6 \%$ considered it very bad. Most of the interviewees $(58.2 \%)$ evaluated the activity performed by the student as effective, whereas $8.2 \%$ considered it ineffective. Conclusions: The students were included primarily in individual assistance activities, and the care provided by the students was well accepted. Both the users' satisfaction scores and their reported expectations were positive.
\end{abstract}

Keywords: physical therapy; public policies and health; academic and professional background.

\section{HOW TO CITE THIS ARTICLE}

Driusso P, Sato TO, Joaquim RHVT, Moccellin AS, Mascarenhas SHZ, Salvini TF. The perceptions of Unified Health System (Sistema Único de Saúde) users about including undergraduate students in Family Health Units (Unidades de Saúde da Família). Braz J Phys Ther. 2013 July-Aug; 17(4):367-372. http://dx.doi.org/10.1590/S1413-35552012005000103

\section{Introduction}

The use of health services is determined by a set of factors that include the organization of the supply, the socio-demographic characteristics of the users, the epidemiological profile of the population and aspects related to service providers, such as the functional integration (e.g., strategic planning, quality improvement) of the professionals (service co-management) and the clinic (e.g., the coordination and continuity of care, the communication among the service providers) ${ }^{1}$.

The Family Health Strategy is part of the primary care strategy of the Ministry of Health (MH); it aims to operationalize SUS principles and presents itself as a continuous and efficient way to increase access to health services ${ }^{2}$. Aiming to strengthen primary care, the $\mathrm{MH}$, in partnership with the Ministry of Education
(MEC), has developed several strategies to guide the training of health professionals using the same logic. Two relevant programs are the Work Education Program for Health/Family Health (Programa de Educação pelo Trabalho para a Saúde/Saúde da Família - PET-Saúde/SF) and the National Program for Reorientation of Health Training (Programa Nacional de Reorientação da Formação Profissional em Saúde - Pró-Saúde $)^{3,4}$.

The PET-Saúde/SF of the Federal University of São Carlos/Municipal Health Service (Universidade Federal de São Carlos/Secretaria Municipal de Saúde - UFSCar/SMS) was first developed in April 2009 by professionals and students in nursing, physical therapy, medicine, occupational therapy and, more recently, physical education. This program

\footnotetext{
${ }^{1}$ Department of Physical Therapy, Universidade Federal de São Carlos (UFSCar), São Carlos, SP, Brazil

${ }^{2}$ Department of Occupational Therapy, UFSCar, São Carlos, SP, Brazil

${ }^{3}$ Center for Health Education, Universidade Federal de Sergipe (UFS), Lagarto, SE, Brazil

${ }^{4}$ Department of Nursing, UFSCar, São Carlos, SP, Brazil

Received: 09/25/2012 Revised: 11/04/2012 Accepted: 01/14/2013
} 
also helps to strengthen the School Network for Health Care of São Carlos and SUS, according to the National Curriculum Guidelines and SUS principles. Among these principles is the notion that community involvement is an important tool for monitoring and evaluating the performance of FHU teams. Thus, the elements in PET-Saúde/SF should also be guided by the perspectives of the users.

Although the MEC recommends including students at different service levels within SUS in the curriculum guidelines, there has been little research into the perceptions of SUS users with regard to student participation. Thus, the present study aims to contribute to this topic by assessing the perceptions of the Family Health Units (FHU) users who have been treated by students in different health-related areas about the inclusion and participation of these students.

\section{Method}

The present study was approved by the Research Ethics Committee of the UFSCar, São Carlos, SP, Brazil, under protocol number 247/2009 (CAAE 1638.0.000.135-09). All of the patients who voluntarily agreed to participate in the study signed an informed consent form, as required by Resolution 196/96 of the National Research Council.

The present study is a cross-sectional, descriptive study with a convenience sample. A total of 518 users of eight FHUs in São Carlos were interviewed. They were selected from the waiting rooms while they were waiting for health assistance from the health care team. Patients over 18 years of age who belonged to a family registered at the FHU were eligible for inclusion in the study.

In April 2010, the questionnaire was administered and fully completed by the PET-Saúde/SF scholarship students in nursing, physical therapy, medicine and occupational therapy while the users were in the FHU waiting room. The users responded verbally to questions, and their answers were transcribed by the students. The questionnaire used in the interviews was developed by PET-Saúde/SF tutors and included ten open- and closed-ended questions that addressed the reason why the user sought care at the FHU and the activities performed by the health students in the FHU. Appendix 1 shows the questionnaire used in this study.

The data were tabulated and analyzed with descriptive techniques, such as calculating the absolute and relative frequencies, means and standard deviations, using Statistica software. The participants' ages were divided into five categories, starting with the minimum value, and divided into ten-year increments; we did not consider the distribution of the data in percentiles. For the variables evaluating the quality and the efficiency of the medical assistance given by the student, $95 \%$ confidence intervals were calculated. To investigate the associations between the demographic variables and the dependent variables (the efficiency and quality of the assistance provided by the student), Fisher's exact test was used. A significance level of 5\% was adopted.

\section{Results}

A total of 518 people were interviewed, including $391(75.5 \%)$ women and $127(24.5 \%)$ men. Of the participants, $58 \%$ reported having a partner (married/ cohabiting), and $42 \%$ were single, separated, divorced or widowed. The mean age was $42.0 \pm 17.5$ years (ranging from 18 to 86 years). The age distribution was as follows: $35.6 \%$ between 18 and 29 years, $20.1 \%$ between 30 and 39 years, $11.2 \%$ between 40 and 49 years, $15.3 \%$ between 50 and 59 years and $18 \%$ over 60 years.

Regarding the users' occupations, 32.2\% (166) stated that they were homemakers, $29.4 \%$ (152) worked in the service/retail sector, $13.6 \%$ (70) were retired, $10.1 \%$ (52) were unemployed, $7.2 \%$ (37) were students, $6.4 \%$ (33) worked in industry and $1.1 \%$ (6) worked in agriculture. Of the users who worked in the service/retail sector, $65.8 \%$ were employed without an employment contract, and $34.2 \%$ had an employment contract.

Table 1 shows the main reasons why the users sought care at the FHU at the time of the study. The primary reasons for visiting the FHU were to obtain a medical consultation or to schedule a medical consultation (27.8\%).

Of the participants, $32.6 \%$ (169) reported that UFSCar students had performed some type of activity for them in the FHU. Table 2 shows the activities that the students performed, as reported by the users. The greatest number of activities are individual activities.

Figure 1 shows the users' opinions about the resolution of the problem in situations that involved student participation. Most of the users (95.7\%) were satisfied with the assistance given by the student. There were no significant associations between this variable and demographic variables. 
Figure 2 shows the users' perceptions of whether their health problems were resolved after receiving care from a student. There were no significant associations between this variable and the demographic variables.

Table 1. Reasons users sought services at the Family Health Unit.

\begin{tabular}{lcc}
\hline \multicolumn{1}{c}{ Reasons } & $\mathbf{n}$ & $\%$ \\
Medical consultation & 120 & $22.6 \%$ \\
Vaccination & 79 & $14.8 \%$ \\
Medicine & 57 & $10.7 \%$ \\
Urgent care/Emergency & 51 & $9.6 \%$ \\
Blood pressure control & 36 & $6.8 \%$ \\
Scheduling consultation & 28 & $5.2 \%$ \\
Dentist consultation & 28 & $5.2 \%$ \\
Nursing consultation & 25 & $4.7 \%$ \\
Pick up examination results & 20 & $3.8 \%$ \\
Accompanying a patient & 17 & $3.2 \%$ \\
Prenatal/Childcare & 12 & $2.3 \%$ \\
Bandage & 10 & $1.9 \%$ \\
Pregnancy test & 8 & $1.5 \%$ \\
Blood glucose/Triglycerides control & 8 & $1.5 \%$ \\
Inhalation & 7 & $1.3 \%$ \\
Seeking guidance & 1 & $0.2 \%$ \\
Physical Therapy treatment & 6 & $1.1 \%$ \\
Injection/insulin & 6 & $1.1 \%$ \\
Pick up milk & 6 & $1.1 \%$ \\
Request a copy of medical records & 4 & $0.8 \%$ \\
Stamping a prescription & 1 & $0.2 \%$ \\
\hline Participating in a physical activity group & 1 & $0.2 \%$ \\
\hline & 1 & \\
Seeking a prompt referral to an orthopedist & $1 \%$ \\
\hline
\end{tabular}

Table 2. Activities performed by the students in the Family Health Units.

\begin{tabular}{lcc}
\hline \multicolumn{1}{c}{ Activities } & n & \% \\
Individual procedures & 88 & $52.1 \%$ \\
Home visit & 34 & $20.1 \%$ \\
Group activities & 23 & $13.6 \%$ \\
Reception & 14 & $8.3 \%$ \\
Participation in research & 10 & $5.9 \%$ \\
\hline
\end{tabular}

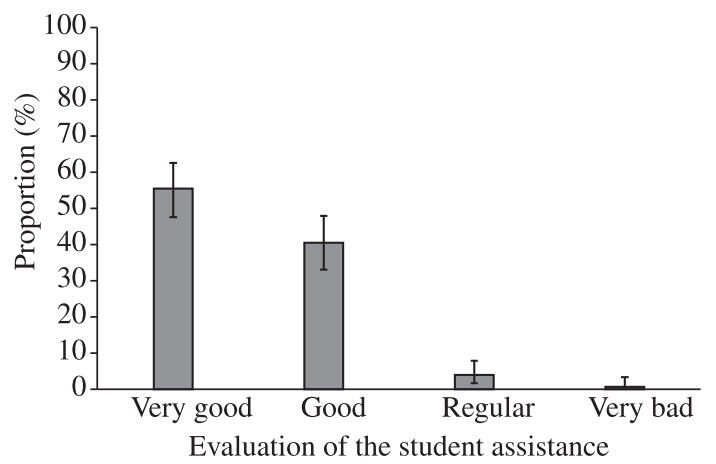

Figure 1. Evaluations of the students' assistance. The bars represent $95 \%$ confidence intervals.

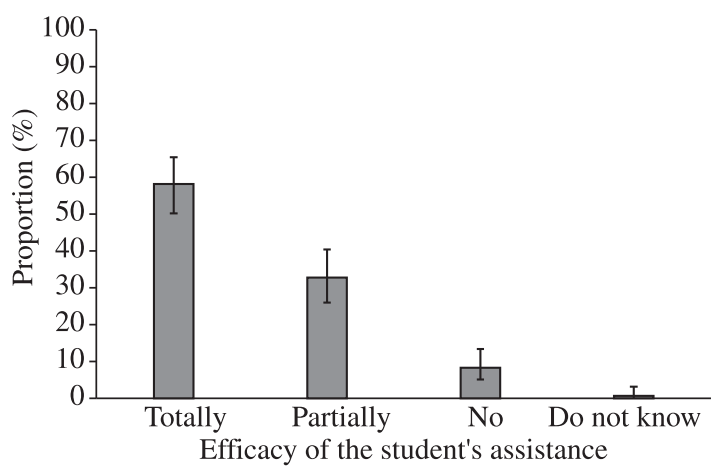

Figure 2. Assessments of the effectiveness of the students' assistance. The bars represent $95 \%$ confidence intervals.

\section{Discussion}

Including students in the public health system is recommended by the National Curriculum Guidelines for undergraduate health-related courses ${ }^{5}$. Thus, many undergraduate students participate in planning and executing activities in the FHUs along with the health care teams.

The present study evaluated users' perceptions about the inclusion of students and found that approximately one third of the users had been treated by students. Most of them (96\%) stated that they were satisfied with the assistance they received, and $58 \%$ of them considered the service efficient, which demonstrates the high quality of the assistance provided by undergraduate students and the users' satisfaction with the inclusion of students in the FHUs.

These findings can be explained by recognizing that the assistance provided by students supports the health care team and makes patient care faster. In addition, students are considerate and dedicated to 
the users; they try to resolve their issues by offering innovations and different types of interventions.

The study by Mialhe et al. ${ }^{6}$ assessed the satisfaction of 182 adult users with the dental care provided by students. The data were collected through semistructured interviews using a questionnaire that consisted of 15 questions addressing aspects of clinical care and the organization of the services provided by the students. According to the authors, the users reported that they did not experience any fear during treatment and characterized the treatment as "great", suggesting that most of them were satisfied with the quality of the dental services provided.

Most of the participants sought care at the FHUs for medical care, vaccinations, medicine, urgent care or an emergency or to schedule medical consultations. Among these reasons, vaccination is the only preventative service, and it is one of the most important ways to protect against specific infectious diseases. The other reasons are related to specific needs, care-related services and intervention measures, which demonstrates that the concept of health is still connected to the healing services provided by the doctor. Despite the efforts of political and health teams to change the paradigm of health from a focus on assistance from the doctor and the process of healing to user-focused strategies for promoting health and prevention, the culture that emphasizes technology, specialized services, medicines and specific interventions is still very present in these communities?

In the present study, only $1.2 \%$ of the users were visiting the FHU for a health orientation, and $0.2 \%$ were participating in a physical activity group, demonstrating the low demand for preventative and health promotion measures. Most of the care provided by the students was individual, demonstrating the emphasis on individual care activities based on the disease-prevention cycle that prevails in the current Brazilian health care system ${ }^{8}$.

However, the emphasis on individual care activities is also a consequence of the students' training. During professional training, a process of internal changes happens with the students as they experience situations, circumstances and experiences throughout the training process. The teachinglearning process is often predominantly directed toward curative and rehabilitative activities and does not allow the students to practice the model proposed by SUS; thus, the students are not prepared to perform public health activities ${ }^{9}$. Consequently, reorienting the professional training and activities of undergraduate students toward the needs of the local population and health promotion and disease prevention activities may ensure better theoretical and practical support for primary health care services ${ }^{10}$.

The MEC, in partnership with the MH, proposed programs, such as PET-Saúde/SF, to foster and stimulate changes in professional training. In the long term, these changes are expected to result in greater involvement of professionals in health promotion and prevention activities. However, training is currently based on the wishes and demands of the enrolled population and a traditional education model.

With regard to the presence of undergraduate students in FHUs, many of the users considered their presence a benefit to the service, to the health care team and to the students who will be health professionals in the future. This perception is important because health promotion emphasizes the participation of the population in defining priorities, decision-making, identifying strategies and implementing them to improve health ${ }^{11}$. Thus, the power of individuals and groups must be increased to enhance self-care, social support and social participation in health-related matters.

The bond between the health care team and the users encourages autonomy and responsibility and expands the clinic while bringing control closer to the setting in which care is provided ${ }^{12}$. Thus, the participation of the community and its involvement with the team, as well as the evaluation of the care provided, are key elements in strengthening primary care, improving the quality of the services provided and reorienting professional training in health.

The interviews were conducted in the FHU, which may limit the ability to generalize the results to the people who use these services. This issue is considered a limitation of the present study.

The present study provides important contributions for training health-related professionals, particularly those in physical therapy. Physical therapy has only recently been included in primary care. Studies about the perceptions of physical therapy in primary care are not yet available. Therefore, the present study may help to characterize the perceptions of current users and to develop strategies that promote the inclusion of students to further contribute to the expectations of SUS users.

In conclusion, the main activities performed by the UFSCar students at the FHUs during this period were individual clinical care and home visits, 
demonstrating that the students were primarily included in individual care activities. The inclusion of students in primary care services was well accepted by the users, and their reports about their satisfaction and experiences were positive.

However, to make the FHUs the primary strategy for reorganizing primary care, they must be technically and politically oriented to enhance the quality of life of users, and they should encourage autonomous and democratic participation.

\section{References}

1. Mendes EV. Revisão Bibliográfica sobre Redes de Atenção à Saúde. Belo Horizonte: Secretaria de Estado de Saúde de Minas Gerais; 2007.

2. Brasil. Ministério da Saúde. Secretaria de Atenção à Saúde. Departamento de Atenção Básica. Política Nacional de Atenção Básica. Brasília: Ministério da Saúde; 2006. 60 p. (Série Pactos pela Saúde, 2006, v. 4). [cited 2012 Sept 18]. Available from: http://dab.saude.gov.br/docs/publicacoes/ pactos/pactos_vol4.pdf.

3. Brasil. Ministério da Saúde. Secretaria de Gestão do Trabalho e da Educação na Saúde. Pet-Saúde: Programa de Educação pelo Trabalho para a Saúde. Brasília: Ministério da Saúde; 2009.

4. Brasil. Ministério da Saúde. Ministério da Educação. Pró-Saúde: Programa Nacional de Reorientação da Formatação Profissional em Saúde. Brasília: Ministério da Saúde; 2007.

5. Brasil. Ministério da Educação. Conselho Nacional de Educação - CNE. Câmara de Educação Superior - CES. Resolução no 4, de 19 de fevereiro de 2002. Institui as Diretrizes Curriculares Nacionais do Curso de Graduação em Fisioterapia. Diário Oficial da República Federativa do Brasil, Brasília, 4 mar. 2002. Seção 1, p. 11. [cited 2012 Sept 18]. Available from: http://portal.mec.gov.br/cne/ arquivos/pdf/CES042002.pdf.
6. Mialhe FL, Gonçalo C, Carvalho LMS. Avaliação dos usuários sobre a qualidade do serviço odontológico prestado por graduandos do curso de Odontologia da FOP/Unicamp. Rev Fac Odont UPF. 2008;13(1):19-24.

7. Conill EM. Ensaio histórico-conceitual sobre a Atenção Primária à Saúde: desafios para a organização de serviços básicos e da Estratégia Saúde da Família em centros urbanos no Brasil. Cad Saude Publica. 2008;24(Supl 1):S7-S27.

8. Freitas MLA, Mandú ENT. Promoção da saúde na Estratégia Saúde da Família: análise de políticas de saúde brasileiras. Acta Paul Enferm. 2010;23(2):200-5. http:// dx.doi.org/10.1590/S0103-21002010000200008

9. Schmidt LAT, Peterlini ACM, Lazzarotto EDP, Nunhez I, Anselmo J, Fernandes TAC et al. A incorporação dos conceitos de saúde e promoção da saúde na formação acadêmica. In: Congresso Nacional da Rede Unida: Anais do V Congresso Nacional da Rede Unida, Londrina. Londrina; 2003. p. 24-7.

10. Ceccim RB, Armani TB, Rocha CF. O que dizem a legislação e o controle social em saúde sobre a formação de recursos humanos e o papel dos gestores públicos no Brasil. Ciênc Saúde Coletiva. 2002;7(2):373-83. http:// dx.doi.org/10.1590/S1413-81232002000200016

11. Brasil. Ministério da Saúde. Secretaria de Vigilância em Saúde. Secretaria de Atenção à Saúde. Política Nacional de Promoção da Saúde. Brasília: Secretaria de Vigilância em Saúde; 2006. [cited 2012 Sept 18]. Available from: http:// portal.saude.gov.br/portal/arquivos/pdf/pactovolume7. pdf.

12. Campos RO. A gestão: espaço de intervenção, análise e especificidades técnicas. Campos GWS. Saúde Paidéia. São Paulo: Hucitec; 2003. p. 122-49.

\section{Correspondence}

\section{Patricia Driusso}

Rodovia Washington Luís, km 235

CEP 13565-905, São Carlos, SP, Brasil

e-mail: pdriusso@ufscar.br 
Appendix 1. Questionnaire for assessing student inclusion in the FHU.

\section{QUESTIONNAIRE FOR FHU USERS}

$1 \quad$ Age

2 Gender

years

3 Marital Status

4 Occupation

$5 \quad$ Why are you here?

What do you need at this moment?

6 Have students (from any health area) participated in any activities related to your care?

( ) female

( ) male

( ) retired

( ) unemployed

( ) homemaker

( ) student

( ) industry

( ) agriculture

( ) services / retail sector

( ) yes

( ) no

( ) don't know

$7 \quad$ Which one(s)?

8 What did you think about it?

( ) very good

( ) good

( ) regular

( ) bad

( ) very bad

$9 \quad$ Was your issue resolved?

( ) totally

( ) partially

( ) no

10 What are your expectations regarding the activities/actions of students with users? 